\title{
Reflections on the Impact of the New Economic, Sociological and Historical Institutionalism in Institutional Social Policy
}

\author{
Vargas-Hernández, José G. \\ Research Professor, Department of Administration, University Center for Economic and Managerial Sciences, \\ Universidad de Guadalajara \\ Email: Jvargas2006@gmail.com, jgvh0811@yahoo.com, josevargas@cucea.udg.mx \\ García-Santillán, Arturo* \\ Research Professor, Administrative-Economic Research Center, Universidad Cristóbal Colón. \\ Campus Calasanz., Veracruz, Veracruz, México \\ Email: arturogarciasantillan@yahoo.com.mx \\ Moreno-García, Elena \\ Research Professor, Administrative-Economic Research Center, \\ Universidad Cristóbal Colón. Campus Calasanz., Veracruz, Veracruz, México \\ Email: moreno.garciae12@gmail.com

\section{Pozos-Texon, Felipe J.} \\ Professor at Instituto Tecnológico de Veracruz and Second year doctoral program student at \\ Universidad Cristóbal Colón. Campus Calasanz. Veracruz, Veracruz, México \\ Email: fpozost@gmail.com
}

Doi:10.5901/mjss.2014.v5n23p571

\section{Abstract}

This paper intends to make a reflection and analysis of the impact of theoretical and methodological frameworks of reference on different neo-institutional approaches in social policy. The paper questions the functionality and continuity of the institutions that are responsible for the functions of designing and implementing programs of social policy, given the profound changes on the environment of economic globalization processes. In this analysis, first it is examined the scope of the new institutional economics, then the role played by institutions in the design and implementation of social policy in the welfare and safety systems is delimited. The method used primarily focuses on critical analysis and reflection. It is concluded that the institutions of welfare and social security must develop the technological, organizational and administrative skills to create and maintain institutional effects that go beyond being conductive to efficiency, effectiveness and equitable development.

Keywords: Institutions, new institutional economics, social policy.

\section{Introduction}

The objective of this paper is to define frameworks that facilitate the sociological, economic and historical analysis of the welfare institutional system to design and implement programs of social policies. Methodological and theoretical frameworks are useful for deciding on the kind of empirical research and the ways in which they make sense of the institutions in charge of wellness practices into more specific and concrete situations.

In this analysis, first it is examined the scope of the new institutional economics, then the role played by institutions in the design and implementation of social policy in the welfare and safety systems is delimited. However, despite the important role and functions of the institutions that have played efficiently, from the changes in the structures of public institutions of security and welfare systems, they have shown their dysfunctions and discontinuities. Finally, the implications of these profound changes in the institutions have in delivering services and policy benefits and social security are determined. 


\section{The New Institutional Economics}

In the late seventies a movement started by many of the social sciences, but especially for institutional theories. This movement begins the history of the administrative reforms of the welfare state under the common concern of a strong fight for the rediscovery of institutions. This new movement is referred to as new institutionalism or neo institutionalism comprising several theoretical and methodological approaches with a common feature that attempt to explain the impact of the social phenomenon known as institutions in the economic, social, political and other issues.

These theoretical and methodological approaches from several broader aspects relate ideals of social sciences and related approaches to the issues of ontology and the concepts of rationality that are played under the common approach of new institutionalism. The neo-institutionalism as a theoretical-methodological approach is delimited from three major approaches: The sociological institutionalism, historical institutionalism and rational choice institutionalism (Table 1).

The sociological institutionalism is related to reforms change stories plus. Historical institutionalism is related to changes focused on the history of structural pluralism. Finally, rational choice institutionalism is related to the traditional administration seeking efficiency. The historical and sociological institutionalisms have in common dynamic point goals, which can be and shape the institutions, unlike the rational choice institutionalism. Moreover rational choice institutionalism and sociological institutionalism share a universal ambition, while historical institutionalism is directed to a middle range theory on the assumption that the history of institutions is very important.

In the rational choice institutionalism, goals are related as exogenous and institutional factors are the strategies and means. Historical institutionalism as the history of structured pluralism is an empirical account of the development of administrative reforms. It is an approach for future research that creates opportunities for complex, difficult process of determining the initial point (Fry, 1995, Richards, 1997).

Table 1. Comparison of the main approaches of institutionalism.

\begin{tabular}{|c|l|l|l|}
\hline & Sociological Institutionalism & Historical Institutionalism & $\begin{array}{l}\text { Rational Choice } \\
\text { Institutionalism }\end{array}$ \\
\hline Institution & $\begin{array}{l}\text { Any social interaction of a quality } \\
\text { that is taken for given. }\end{array}$ & $\begin{array}{l}\text { Formal and informal structures, not } \\
\text { classes or rules. }\end{array}$ & $\begin{array}{l}\text { Formal and informal rules } \\
\text { and procedures. }\end{array}$ \\
\hline Ontology & Strong constructivism & Weak constructivism & Realism \\
\hline Rationality & Institutional appropriateness & Appropriateness & Instrumentalism \\
\hline Objects of key study & Organizational fields. & Public policy and power constellations. & Results of public choice \\
\hline Examples of authors & $\begin{array}{l}\text { Brunsson, DiMaggio, March, } \\
\text { Meyer, Olsen, Powell, Scott }\end{array}$ & $\begin{array}{l}\text { Hall, Pierson, Rothstein, Sckocpol, } \\
\text { Skowroneck, Steinmo, Thelen, Weir }\end{array}$ & $\begin{array}{l}\text { Levi, Hedström, North, } \\
\text { Shepsle, Weingast, } \\
\text { Williamson }\end{array}$ \\
\hline
\end{tabular}

Source: Own elaboration based on the contributions of different authors.

These approaches of social theory are trying the emergence, development and evolution of institutions associated with the practice of social welfare. However, analysis from the new institutional economics, are scarce. None of the analysis of welfare institutions and social policy operates as a coherent framework for the sociological and economic welfare benchmark study, although these investigations help to provide important elements for analysis.

From the perspective of the new institutional economics, social policy reflects and reinforces the distribution of power in the economic and social structures and cultural values contextualized between social groups and gender. The logic of the relationship between the central government of a state in terms of social welfare institutions and domestic institutions, tended to be patriarchal, generate competitive tension created by the coexistence of institutional forms that are key to understanding dysfunctions of gender in the division between the public and private.

The contextualization of the analysis from the new political economy requires an understanding of the changes in the economic, social and political dynamics of legislation and the implementation of social policies of the society under study. The analysis focused on comparative historical institutionalism enhances the understanding of the evolution of social institutional and organizational diversity from a historical perspective and diversity required to examine the institutional evolution. The institutions are perceived as local policies where relations, defense, negotiation and struggle between different social groups occur as a matter of routine (Clegg, 1989). Therefore, institutional change processes serve to focus and intensity of political struggles. 
The new institutional economics assumes that institutions of states, markets and civil society are the result and in turn are contributing to cultural and institutional environments in which they are historically located. This analysis must distinguish the conditions of the possible solutions of institutional performance against institutional environments. For example in the relationship between government bureaucrats and state business groups are characterized by an embedded autonomy (Evans, 1995).

This embedded autonomy is a framework for programming a coherent, connected and cohesive development that emerge as a result of a particular set of social and economic relations. Therefore, these social and economic relations unite state institutions with the institutions of society and provide institutionalized channels for the continued negotiation and renegotiation of goals, social policies and social security.

The approach of the sub-socialization of impersonal institutional arrangements with improbable predictions of universal order or disorder (Granovetter et. al, 2004) and the approach of involvement (Polanyi, 1944, 1957, Beckert, 2007) assume that the social structure determine the distinction between markets and hierarchies used by neo institutional economists to explain the problem of Coase.

An existing institutional arrangement represents an established order, a pattern of interest and the distribution of benefits among different stakeholders. The notion of involvement and embedded micro level refers to connections intra and extra community networks while at the macro level refers to the relationship between the state and society, institutional capacity and credibility.

The institutional credibility of the new democratic governments is based on its ability to nurture welfare institutions of civil society that prevent anomie and alienation of the citizen (Hagan, Merkens and Boehnke, 1995; Mishler and Rose (1997) Inglehart (1977) and Woller, 1996). This citizen anomie is an endemic element of all social transformations (Galtung, 1995).

Comparative neo institutionalism expands institutional performance empirically no normative when you consider that the embedment in the state - market - society relations at the macro level in the administration of social policies may be synergistic if autonomy is achieved with institutional coherence, competence and capacity as components of organizational integrity. Thus, the existence of welfare institutions are distinguished not by their informal and formal qualities always present but rather by the structures of relationships and networks related between and within firms.

Since the approach of the new institutional economics, the notion of embedment is useful in explaining the economic relations of the institutions of the welfare systems and social policy. The high density and characteristics of social and economic relations that are made with the implementation of social policy programs which impose significant restrictions on communities' members trying to make changes from the membership to larger welfare sharing networks, extensive and sophisticated coordination by formal and complex institutions and the welfare state.

Forms of exchange are intricate with the networks of social relations problems in coordinating exchanges of benefits because of the implications for participation in the new institutional forms. The trend of public participation in the context of social policy tends to be automatic, unrestricted, dangerously dysfunctional political and administrative systems (Cupps, 1977:478). The inquiry became the norm, institutionalized as a standard component of the political process.

During the 1990s, the laws are given to those affected by the new regulations on the right to negotiate the content of social policy. Therefore, the decision process has moved beyond consultation to meet with decision rules. The comparative neo-institutionalism explicitly identifies the autonomous social relations and embedded in the administration of social policy as different forms of social capital. Social capital is defined as the nature and degree of personal relationships in the community and institutional, which actually determine the types and combinations of these relationships.

The neo-institutional economics tests that contractual arrangements in the market do not exceed the hierarchical relationships that can cause problems arising from the relationship between the principal-agent, such as adverse selection and moral damage that transaction costs from the development and monitoring contracts (Le Grand and Bartlett, 1993: 19-34). The concerns of classical economics and sociology focus on the nature and extent of social relations that vary within and between different institutional sectors. However, the tasks performed by these relationships necessarily change comes when the economic exchange become more sophisticated.

Trust and norms of reciprocity, justice and cooperation between agents of welfare and social security are attributes of nourished benefits by particular combinations of social relations that are undeniably important to facilitate and enhance the efficient institutional performance. However, these attributes do not exist independently of social relations. In any case, the existence of little or a lot of social capital in any given institutional level can impede economic performance of institutions.

The neo-institutional comparative development (Portes and Sensenbrenner, 1993) has discussed the different elements implicit in the positive aspects of both groups and individual communities and institutions of social policy where 
its social capital can help produce other desirable qualities in public goods and benefits of the groups. If grown and maintained social capital in social organizations and beneficial relationships between communities and institutions of the welfare system, it may dissipate the negative effects, discrimination, etc.

The neo-institutional approach to macro level developed by Portes and Sensenbrenner (1993) identifies synergistic institutional relations of state and society encouraged in developing countries where the socio-political and economic environments are more predatory. However, the conceptual and empirical limitations of comparative institutional literature suggest the need for a broader and more dynamic model that covers both domains.

The neo-institutional comparative literature identifies different types of social relations that contribute to the formation of social capital, whose presence; absence and interaction have implications for the effectiveness and efficiency of social policy programs. The cohesive and coherent institutions strive to empower a diverse group of civil society to facilitate the development of beneficial autonomy accountability both in and between different social groups' beneficiaries of social policies.

The construction of rationality of agents (rational choice theory or instrumental rationality) and the approach of the outcome of institutions, rules or primary culture (Institutionalism), to explain or refute the arguments of the presence of social relations in any place and time, limit the scope of research in the field of public policy. The analysis focused on social structural explanations of economic activity identifies the types and combinations of affected social relations, institutional environment that shapes them and their historical emergence and continuity. It is a more consistent approach for the study of social policy.

Institutional settings affect the forces that shape the governance and governability of power structures that make up the State. Institutional configurations are formed by the relationships of the structures of institutions and relevant forces with and within the project of state building that is created with full purpose of constitutive fiction in will of statehood varies in space, porosity and shape of public / private division (Gauri Viswanathan, 1995:31; Suad, 1997; North, 1996) emphasizes the need to adapt to changes and take risks to achieve efficiency among institutions in the privatization process and solve social problems.

In this structural approach it is considered that social policy testifies the class struggles in defense of their own interests (Baldwin, 1990), the emergence of the institutional structures of the welfare state and conflicts of modern society (Lowe, 1997) to achieve better levels of welfare and social security. The collective action problems that relate to institutional historical processes involve mediating variables as the degree of coordination of beneficial interactions with the dimensions and combinations of social relations are more constructive.

\section{Institutions of Social Policy}

The nation-state is the most mythologized institution of modern institutions (Chandhoke, 1995) in direct reference to welfare institutions. Social policy has always been taken for granted and has played an important role in the design of the welfare state after the war. It has become the cliché of the new social policy. Rather than sustain discussing in theoretical and methodological approaches on traditional social policy, analysts and scholars have focused on descriptions of the programs emphasizing good wishes to achieve social welfare goals.

The evolution of industrial capitalism and democratic institutions have given rise the economic challenges of the working class to find a possible solution in the relationship between voters and the state. In this sense, social policy passes to the field of struggle changing classes, with fear to disorder and popular mobilization. With the development and expansion of trade and social stabilization, institutions of national welfare system weaken in protecting individuals against the harshness of market institutions.

The analysis of economic phenomena and therefore of social policy from the perspective of the role of institutions and norms (institutionalism) was abolished in the nineteenth century when the classical political economists and utilitarian economists were based on the Wealth of Nations rather than the theory of moral sentiments. Weber (1991) considered exercisable confidence in social policy that formal institutions and arrangements of particular groups use different mechanisms to comply with the agreed rules of conduct. For example, while bureaucracies use rational legal mechanisms and families use informal mechanisms of replacement social policy. Comparative institutional academics extend the Weberian thesis arguing the existence of two key organizational dimensions, structures that establish and perpetuate capacity and credibility and internal relations to beneficiaries and stakeholders

The analysis on bio power of Foucault $(1966,1996)$ point directly to the design and implementation of the practices associated with welfare institutions. The institutions responsible of welfare practices are being involved in process control through the exercise of different forms of power over other participants. Field of power exercised by institutions over citizens occurs in a space relationship between agents and institutions that share ownership capital to exercise the 
dominant economic, cultural and social positions.

The institutional model of welfare state, according to the type of Titmuss (1974) is that implementing social welfare programs, redistributes resources and makes the goal of equality. Institutional welfare systems are based on the promotion of the values of solidarity and equality are universal if the benefits derived from general revenue.

The other two models are the residual welfare state with programs that merely guarantee a minimum level of support and achievement-performance model based on industrial principles of achievement and social status. The welfare systems based on the achievement gains provide related benefits paid as a reward for work and based on contributions to social security but maintain status differences between social groups.

Conservative governments since 1974 have been making radical and permanent changes in social welfare policies and welfare institutions inconvenient to the welfare state model. Jessop $(1990,1994)$ argues the transition Schumpeterian welfare state in which the local full employment is prioritized for international competitiveness and redistributive social rights take second place in a productivity orientation and reformatted social policy. The traditional instruments of social policy implemented are different to the professional model. The changes have been profound, from an approach to the role and functions of the welfare state in the provision of welfare services for all to a different role of providing support only for the poor in a more production-type of disciplinary and social policy.

Social capital as a theoretical approach to the analysis of social policy is based on and extends the work of Durkheim (2003), Weber (1991) and Simmel (1986) on the functions of different types of social relations that affect institutional outcomes. The analysis of social capital on public policy from the 70 s with theoretical and empirical approaches supported by studies compared the new institutional economics and sociology of economic development deal with institutional relations of the state and society at the macro level.

The framework of social capital can have more influence for geographic analysis of institutions that transcend the micro and macro levels. It seems to be fruitless. Strategic research (Merton, 1987) facilitates the analysis of dilemmas of development in poor societies. For example, bottom-up tasks of coupling and uncoupling between social groups with expansive economic requirements and the establishment of a durable synergy among development institutions consistent with its constituent groups. Also, how interactions between social groups and constituents change over time and the relative importance of each dimension.

Exemplified with microfinance institutions Grameen Bank in Bangladesh that benefit groups of poor women who achieve high recovery rates in a complex institutional structure that involves rotating savings, credit associations, collateral sources, etc. The relationships of the beneficiaries were formed spontaneously in a structure from the bottom up as a reaction to the isolation of traditional financial institutions. This initiative is promoted by external nongovernmental organizations to the communities they serve.

The concept of habitus (Bourdieu, 1996, 1994, 1993, 1990, 1980; Calhoun, 1993) is relevant in welfare institutions as contact between institutions and social policy beneficiaries, in the field of welfare. The field welfare model points to the way the economic capital in social policy programs is channeled. In this dynamic field welfare model, different factors and mechanisms involved are influencing welfare efforts internally. Therefore, the different forms of social policy such as health, education, food, housing, employment, social security, etc.., display structures of domination that activate different habitus and interests.

The field model of Bourdeiu provides a realistic tool for the analysis of the institutions and practices of welfare (Peillón, 1998) because it can determine the type and level of development and welfare implications of institutions, policies, programs and practices being social welfare.

In Britain for example, the discussions approach the analysis of Kramer (1981) that emphasize the role of the voluntary agencies sector and their role in the welfare state. The new British model being driven by Thatcher is committed to parliamentary sovereignty and the insertion of intermediate institutions such as the civil service of the executive authority. Consequently, in many areas of state power, the trend toward centralization has increased, as opposed to the persecution of decentralization processes (Martin, 1998). As a result, life has become harder to accept excuses and apologies that give way to a more consumerist social policy as part of the cost increases economic, social and demographic change.

The theory of communicative action made by Jurgen Habermas (1987), which analyzes the colonization of the life of the world in relation to social welfare, zooms to the institutions of the welfare state that exchange obtaining legitimacy for the monetary rewards. Therefore, if institutions are being supported to serve and are allowed to use their own instruments, then you simply can colonize the world of people.

The feminist literature on welfare institutions are aimed to analyze the development of social policy programs. The analysis focused on feminist theories connect the reproduction of gender inequalities with the welfare institutions and focus on the different ways in which social policy supports and reinforces the dependence of women. Governmental and 
local welfare institutions can develop different patriarchal welfare forms to regulate and govern the conduct of gender and kinship through different forms and codes of communication, modes of operation and practices to subsidize the continuities between the different economic, social, cultural and religious spheres, etc.

Feminist critiques are directed to consider the social policy of the welfare state as a set of supportive relationships and dependency within families, providing space for women to keep the roles of care and control of reproduction.

The French approach to institutionalism supported by the European political philosophy gives rise to the concept of social exclusion and its political implications and relationships with markets in the ownership approach (Sen, 1987), the state, citizenship, and civil society. The social exclusion emphasizes agency and the role of social institutions. By extending the concept of ownership, Bartlett (2005) examines the significance of the lack of assets to the continued poverty of the poor.

For example, when the institutions of the welfare system do not have the will to deal with citizens being considered as very risky, as in in the case to support programs of housing finance with high interest rates and informal financial institutions, there are developed segmented markets with more adverse consequences for those excluded. The consumer paradigm in welfare public sector reform is easily susceptible to manipulation by politicians and public administrators to strengthen and legitimize their institutions and institutional power against producers and consumers.

The connection of the bureaucratic foundations and functions between different institutional settings (Rueschemeyer and Evans, 1985) of the welfare system and the relationships of social capital as a moral appeal, trust and cultural mechanisms define and reinforce the status borders of the beneficiary groups of social policy. However, conservatives relate the state with society in a zero-sum game, while the institutions of civil society earn what the state loses. However, it is left unresolved the relationships with social capital infrastructure and content, media and message of social relations. The infrastructure of welfare institutions from the supply side and the behavior of the beneficiaries from the demand side should be considered in the design and implementation of social welfare programs.

States with highly institutionalized political and administrative systems emphasize organizational designs for the formulation and implementation of social policy Aucoin (1990). The structural and institutional reforms of the welfare system seem inevitable to change the traditional model of public administration as they do not always result in the institutional logic of the amalgamation of institutional, contextual and temporal elements. However, despite the antibureaucratic and post-bureaucratic clamor of public sector institutional reform of the welfare system, the results are uncertain as involving institutional bargaining between public bureaucracy and professional power trying to reconstitute themselves their autonomy and domination within the new administrative culture and context.

Institutional reforms of the welfare system can be considered as interactive processes between various institutional and bureaucratic actors actively involved in strategies that promote self interest in contingent and ambiguous contexts. The means to pursue institutional reforms of the welfare system vary considerably in the locus and focus depending on the history, politics and institutional elements involved on nation states, national motifs and styles of reform. The application of techniques of New Public Administration redesigned the institutions of the welfare state by amending State Management structures, behaviors, processes, culture, ideologies and practices in welfare policies (Clarke and Newman, 1997).

In a historical and institutional context characterized by a heterogeneous plurality of needs and interests in conflict, the reforms of the new public management of social welfare institutions, under the approach to implementation, decentralization is encouraged for subjects institutionally autonomous, and consciousness and responsibility increase.

However, it is the social classes in political systems where are obviously reflected those genuine changes that are at least partially and imperfectly brought by the administrative reform. Beyond a perfect arrangement between intentionoutcome and impact on the processes of administrative reform is considered the dominant value that establishes specific policy legacies and institutional arrangements including and perhaps particularly interspersed with specific settings to individual nations.

The orientation of decentralization process of social welfare institutions is part of an institutional context based on the cooperative principle subject to a dualistic logic aimed at determining the spacing between the respective areas of responsibility. Decentralization rearranges the institutional processes characterized as a sign of the increase in unit needs, the formation and growth of both the federal or unitary state and local governments.

The notion of institutional subsidiarity supports initiatives of private organizations, associations and social groups with the participation of public institutions. Under the principle of subsidiarity, decentralization occurs in two phases that are logically distinct but closely connected criteria for determining allocation of powers within different institutional levels on one side and the actual distribution of singular powers of the other side.

In the decentralized organization are redefined and redesigned the relationship between the structures of the national state and local organizations and institutions with autonomy as equity. Territorial local institutions are part of the 
structures of the unitary state as an expression of the will of the parties defined territorially of the Community State. However, the decentralization processes guarantees a small balance of power between the different institutional levels left for negotiation.

Subtle changes in the design and implementation of social policies modify the financing of benefits to transform the institutions that formulate and implement progressive policies in regressive or vice versa, taking into account the comparative analysis of local and international situations. The government is no longer just confined to the nation state, but may now involve a range of public and private institutions ranging in levels from national to local, community and neighborhood, to achieve its goals of providing social welfare. This leads to continuity in new forms of governance and fragmentation in the delivery of welfare benefits and social security.

Thus, the creation of internal quasi-markets and government contracts as used in the eighties, for example, differ from the involvement of an active and democratic citizenship embedded in voluntary social organizations. The basic structure and operating methods of social non-profit organizations are characterized by an institutionally separate sector of the state, which allocates and distributes non-profit resources with its own forms of self-government and voluntary participation (Salamon and Anheir, 1997; Johnson, 1997).

Social exclusion as a framework for the analysis of relationships in a welfare system focuses on the agency, institutional structures, social processes, contexts and multidimensional economic, political and social to relate poverty, employment and social integration. The analysis takes into account the economic, social and institutional forces that cause or prevent social inclusion as well as social policies that address social exclusion. The analysis of social exclusion is related to the implications of economic, social, civil, political, cultural and other rights, improved lifestyles, market access, social participation and identity, etc.

The research conventional perspective focused on internal efficiency of welfare systems risks diverting attention away from the real problems of the government and public administration institutions that are structural problems requiring interagency coordination (Metcalfe and Richards, 1993: 118).

\section{Dysfunctions and Discontinuities}

The sub-governed societies by the rule of law and the State are so hostile to equitable development as economies over ruled on without achieving both efficient and effective results. According to Suad (1997), in the South there are postcolonial states with welfare institutions and social security impacted by their colonial experience in pre-state societies. The central institutions of the organization hierarchically structure economics, society, politics, religion, etc., are bureaucratic formal and dominant. In such societies, institutions of centralized welfare displace to local ones, tend to evaluate and institutionalize the boundaries and discontinuities between different arenas of social welfare and more companies maintain the state level, especially in highly centralized states.

The economic development policies neglect the formation of social capital in their proposals to strengthen market economies and democratic institutions of social welfare. Often, welfare institutions justify their dysfunctions with interventions aimed at different objectives, such as ecology and democracy, rather than the values of the people who are the recipients of the activity of public policies, the values that reflect the theoretical precepts own properly by people, interpretations of the nature or principles of government.

In a changing context of globalization processes and demographic, are criticized the scope of social policy. The concept of social exclusion is used in discussions of welfare institutions and social policies for the analysis of the emergence of patterns in a range of dimensions of those in poverty, deprivation and social and economic disadvantage (McPherson, 1998). It is a complex notion of situations and processes of marginalization and economic deprivation and social isolation experienced by individuals that occurs in fragmented societies in their social relationships that result in dualities, breakouts and social cohesion.

Empirical research reports that the processes of social exclusion are the result of interactions of market institutions, the state, citizenship and civil society. Social exclusion is pressured by rising trends such as the globalization process associated with the loss of sovereignty nations and capacity decisions, poor asset allocation hindering its availability for large segments of the population and the economic, social and political structures that determine the exercise of power and the status of various social groups. Gamble and Payne (1996) questioned whether regional economic blocs are a growing response to global forces that enable the development of politically stronger economic institutions (George, 1996).

Because there are no social institutions capable of strengthening the civic virtues and demand their application, they leave to the State the enormous task of institutionalizing the necessary functions to meet what society has lost. Therefore, if the moral structures of social institutions like the family and the church lost its importance in teaching the 
standards of ethical behavior, the claim of welfare rights that are available are considered as rational actions rather than need.

The inefficiency and rigidity of bureaucratic institutions that fail to achieve results expand their political activism as renegade programs to include support for social welfare and humanitarian relief of community organizations and as a last resort to international philanthropic organizations. It is difficult to determine the conditions under which dysfunctional, destructive and dying institutions in states that are predatory, weak or indifferent, continue administering social policy programs without giving way to the emergence of institutions in the welfare system which should be more functional, constructive and responsible active developers.

There is abundant evidence of abuse, corruption and scandals in the public sector institutions that are responsible for the function of administering the programs of social policies despite the good intentions of professional bureaucrats and actions guided by codes of ethical behavior. The benefits of the noblest purposes are lost in the maze of corruption, implementation and misapplication in logistical problems for effective and efficient delivery, etc.

In the end, many institutions of social welfare development, rather than the poor, marginalized and socially excluded, are the beneficiaries, depending on the type of social relations and political circumstances to be taken into consideration. For example, determined social policy professed its intention to improve the condition of many of the poor, benefits only certain persons and institutions in terms of income, status and power.

Deficiencies and social deprivation combined with financial institutions and public organizations in civil society allow benefits to organizations and voluntary agencies and philanthropic programs for social welfare sectors. Perceptions of welfare reforms, the political will of governments and political parties and the inertia of welfare institutions to implement programs and practices are factors to consider.

The relevant legal conditions in progressive social policy become inflexible and impersonal. Strategies to design and implementation of social welfare policies are aimed at achieving macroeconomic results without contributions to micro - institutional foundations on which they depend. Over-exploiting incentive structures and flexibility than other markets provide clearly define the institutional foundations of improving human welfare and raising the productivity of the poor.

\section{Implications for the Design and Implementation of the New Social Policy}

The frames of reference require sociological and economic institutions and practices of welfare are located in the internal dynamics of a particular social and economic context. In programs of universal social policies interactions between institutions and beneficiaries take on a different character taking into account the different areas of the welfare system. History shows with evidence that the economic performance of a company depends on its institutions. Institutional arrangements in the relations between state institutions, civil society and the market that are incorporated under sensitive and sensible social policies are established.

All these factors determine the functions of the state, society and market approaches to development projects adopted by governments and the allocation and accumulation of resources, social policy programs for poverty reduction, economic growth and structural transformation. Civil society can be reconstructed under a design of emancipatory nature (Chandhoke, 1995) from establishing that all welfare institutions in civil society are equally susceptible to the democratization processes. In some situations, social exclusion is reduced by institutional innovations that compensate for market failures in the provision of public goods and services.

The ethical standards result of moral structures that guide individuals and were taught by other social and religious institutions are complementary but need not be part of the social policies of the state. In societies where collective action problems are resolved efficiently and effectively, institutional and organizational differences are abysmal compared to that society in which its institutions are in constant mutual defection. This defection leads to hostilities, frustrations and inconveniences, as inevitable cultural results.

The relations between the institutions of the state, society and market remain in the structural forms of top-down development agenda which should be involved the communities it seeks to serve social policy programs to achieve credibility and effectiveness. This type of institutional structures facilitates the introduction and institutionalization paradoxically supported from the bottom up. Therefore both types of institutional structures are complementary and necessary to achieve positive sum purposes of social programs and welfare policies.

In social riots the individuals discover the power and capabilities to act as forms of political and economic -driven new institutional arrangements for social welfare to create the social compact that best suits your organization demands.

In the spatial expression of social and welfare policies, an error in the design and implementation is the lack of consideration of space for traditional security institutions and welfare between communities as part of cultural and social 
components of their lifestyle. Economies tend to be endogenous in social welfare responsibilities focus on local institutions such as family and community charitable institutions with more appropriate feedback systems allowing them to be self-sustaining and even experience dynamic growth returns, except that they are more focused on the needs of the beneficiaries.

On initiatives of welfare programs from the bottom up, the more informal communities to levels of family require connections more formal and extensive levels of extra community institutional systems. These connections must be forged so that the incremental integration may accumulate in new forms of social capital involving non-members the community in initiatives of development programs focused on social policies. However, many concerns arise here, for example, military groups and mafias emerge to provide private and social protection and social security that formal public institutions designated cannot.

The institutional development of social and philanthropic organizations such as churches, private charities and governmental and quasi-governmental organizations as they present themselves like they are who keep and store the values of service for social welfare as ideals, when what is an appropriate course to pursue their own agendas and interests. Institutional and organizational dynamics can explain the results of any social policy with an institutional structure. Significant effects include competition in management projects of social policies programs and the balance of the recipients or beneficiaries of such welfare programs.

The institutional development of the welfare system of ethnic communities is hampered by the tenuous legal status and lack of recognition that results in a large discrimination against certain social groups that weakens their identity and commitment to the institutions. These social groups thus become excluded from the social, civic, financial and government institutions, etc. to such a degree that they become enclaves where there are only focused institutions on organizing family to meet basic requirements of safety and credit. However, it may result paradoxical that there are not the financial resources the more necessary to the institutions.

The assumption of state governance remains for other institutions with a development agenda without having the ability to give answers to transparent processes and accountability, while cultivating a more just and inclusive social environment with beneficiaries. Creating a synergistic environment involves developing relationships at various levels between groups and local communities with external social relationships and more extensive to the civil society, between civil society and institutions at the macro level and between institutions of corporate sectors.

The role of state institutions is fundamental in the tasks of social policy to attack simultaneously from a global and systematic overview of the state that involves coordinated action in the primary markets, political institutions and cultural values and from the perspective of the social actors themselves. In this situation, we need to strengthen the capacities of social actors (Figueroa, Altamirano and Sulmont, 1996: 89-92). At the micro level social policy programs and social security policies should seek to nurture participatory organization of beneficiaries who should be empowered to assume increasing levels of responsibility and commitment to their own welfare and human development while building relationships between local communities and formal institutions.

The regional development agencies to promote social policy programs for the welfare and social security institutions are regionally based and publicly funded outside the mainstream of central control and administration of local government designed to promote economic development (Halkier and Danson, 1996).

The recipients or beneficiaries of social policies and programs of social security may initially require basic induction but in the long run the primary measures of success of the program should be extended to all involved. All actors and stakeholders involved should incrementally take responsibility for the viability of the new welfare institutions and mechanisms are established to ensure access to the institutions of the welfare system and to support their participation. Welfare institutions must develop the technological, organizational and administrative skills to be able to create and maintain institutional effects that go beyond being conductive to efficiency, effectiveness and equitable development.

\section{References}

Aucoin, P. (1990) Administrative reform in public management: Paradigms, principles, paradoxes and pendulums. Governance. Vol. 3, Issue 2, pages 115-137, April 1990.

Baldwin, P. (1990). Les classes moyennes et l'Etat-protecteur de l'après-guerre: Le cas français et le cas allemand, in Mission Interministérielle Recherche Expérmentation, Les comparaisons internationales des politiques et des systemes de sécurité sociale: Colloque de recherche, (Paris, nd); reprinted as Class Interests and the Postwar Welfare State in Europe: A Historical Perspective, International Social Security Review, 3 (1990).

Bartlett, S. (2005). An Alternative Model for Responding to Children in Poverty: The Work of the Alliance in Mumbai and Other Cities. Children, Youth and Environments 15(2): 342-355. Retrieved on 27 December, 2013 from http://www.colorado.edu/journals/cyel.

Beckert, J (2007). The Great Transformation of Embeddedness: Karl Polanyi and the New Economic Sociology. MPIfG Discussion Paper 07/1 Max-Planck-Institut für Gesellschaftsforschung Köln. Max Planck Institute for the Study of Societies Cologne. January 2007. 
Bourdieu, P. (1996). The rules of art, genest and structures of the literary field. Polity Press. Cambridge.

Bourdieu, P. (1994). Raisons pratiques. Sur la théorie de l' action. Editions du Seuil. Paris.

Bourdieu, P. (1993). Sociology in question. Sage. London.

Bourdieu, P. (1990). In other words. Essays towards a reflexive sociology. Polity Press, Cambridge.

Bourdieu, P. (1980). The Logic of Practice. Stanford, Stanford University Press.

Calhoun, (1993). Habitus, field and capital: the question of historical specificity, In C. Calhoun, E. Lipuma and M. Postone (Eds.) Bordieu: Critical perspectives. Polity Press. Cambridge.

Chandhoke, N. (1995) State and Civil Society. Explorations in political theory. New Delhi, Thouand Oaks, and London: Sage Publications.

Clarke, J. and Newman, J. (1997). The Managerial State: Power, Politics and Ideology in the Remaining of Social Welfare (London, Sage).

Clegg, S. R. (1989). Frameworks of power, London: Sage.

Cupps, D. S. (1977). Emerging Problems of Citizen Participation, Public Administration Review 37 (1977): 478-487.

Durkheim, É. (2003), Las reglas del método sociológico. Buenos Aires. Editorial Gorla;

Evans, P. B. (1995). Embedded autonomy: States and industrial transformation. Princeton, NJ: Princeton University Press.

Figueroa, A; Altamirano, T. \& Sulmont, D. (1996). Social exclusion and inequality in Peru. Geneva: International Institute for Labour Studies.

Foucault, M. (1996). La vida de los hombres infames. La Plata. Caronte.

Foucault, M. (1966). El nacimiento de la clínica: Una arqueología de la mirada médica. México, D. F. Siglo XXI.

Fry, G.K. (1995). Policy and Management in the Civil Service. Hemel Hempstead: Prentice Hall, 1995.

Galtung, J. (1995). On the social costs of modernization: Social disintegration, atomie/anomie and social development. Geneva, Switzerland: United Nations Research Institute for Social Development.

Gamble, A. and Payne; A. (eds). (1996). Regionalism and World Order. London: Macmillan 1996.

George. F. (1996). The Trade Policy Review of Indonesia. The World Economy: Global Trade Policy. 1996:101-17.

Granovetter, M., et al. (2004) Polanyi Symposium: A Conversation on Embeddedness. In: Socio-Economic Review 2, 109-135.

Habermas, J. (1987) The theory of communicative action, vols I and II. Polity Press. Cambridge.

Hagan, J.; Merkens, H. and Boehnke, K. (1995). Delinquency and Disdain: Social Capital and the Control of Right-Wing Extremism Among East and West Berlin Youth. American Journal of Sociology Volume:100 Issue:4 Dated:(January, 1995). Pages: 1028-1052.

Halkier, H. and Danson, M. (1996). Development agencies and new-model regional policy. A survey of trends in 30 European regions. Paper presented to the European Urban and Regional Studies Conference, Durham, 11-14 April.

Inglehart, R. (1977). The Silent Revolution: Changing Values and Political Styles among Western Publics. Princeton, NJ: Princeton University Press.

Jessop, B. (1994). Post-fordism and the state, in Ash Amin (ed.), Post-Fordism, Oxford: Blackwell, 251-79.

Jessop, B. (1990). State theory. Putting capitalist states in their place. Cambridge: Polity.

Johnson, N. (1997). Book review. Journal of Social Policy, 26 part 4, Oct 97, 559.

Kramer, R. M. (1981). Voluntary agencies in the welfare state.University of California Press.

Le Grand, J. and Bartlett, W. (1993). Quasi-markets and social policy: the way forward? In: Le Grand, Julian and Bartlett, Will, (eds.) Quasimarkets and social policy. Macmillan Press, Basingstoke, UK, 202-220. ISBN 0333565185

Lowe, R. (1997). The state and the development of social welfare, in Pugh, M (Ed.), A companion to modern european history, (pp. 45-69), Blackwell Publishers, 1997. ISBN: 0631192182

Martin, J. Smith (1998). Reconceptualizing th British State: Theoretical and empirical challenges to central government. Public Administration. Vol. 76. Spring 1998. 45-72.

Metcalfe, L. and Richards, S. (1993). Improving Public Management. London: European Institute of Public Administration/ SAGE

McPherson, S. (1998). Social exclusion. Journal of Social Policy, 26 (4): 533-541.

Merton, R. (1987). Three Fragments from a Sociologist's Notebooks: Establishing the Phenomenon, Specified Ignorance and Strategic Research Materials. Annual Review of Sociology, 13,1-28, 1987.

Mishler, W. and Rose, R. (1997). Trust, Distrust and Skepticism: Popular Evaluations of Civil and Political Institutions in Post-Communist Societies. The Journal of Politics, Vol. 59, No. 2 (May, 1997), pp. 418-451.

North, D. C. (1996). Institutions, Organizations And Market Competition, Economic History 9612005, EconWPA.

Peillón, M. (1998). Bourdieu's field and the sociology of welfare, Journal of Social Policy, 27 (2): 213-229.

Polanyi, K. (1957). The Economy as an Instituted Process. In: Karl Polanyi/Conrad M. Arensberg/Harry W.

Polanyi, K. (1944). The Great Transformation. Boston: Beacon Press.

Portes, A.; Sensenbrenner, J. (1993). Embeddedness and Immigration: Notes on the social determinants of economic action, in: American Journal of Sociology, Vol. 98 , pp. $1320-1350$

Richards, D. (1997). The Civil Service under the Conservatives 1979-1997. Brighton: Sussex Academic Press, 1997.

Rueschemeyer, D. and Evans, P. B. (1985). The State and Economic Transformation: Toward an Analysis of the Conditions Underlying Effective Intervention. In Evans, P. B.; Rueschemeyer, D. and Scokpol, T. Bringing the State Back In. Cambridge University Press. pp. 44-77.

Salamon, L. M. and Anheir, H. K. (eds.) (1997). Defining the non-profit sector, A cross-national analysis. Manchester University Press, Manchester, 1997.

Sen A. (1987). Commodities and Capabilities. New Delhi: Oxford University Press, 1987.

Simmel, G. (1986). Sociología 1, Estudios sobre las formas de socialización. Madrid. Alianza.

Suad, J (1997). The public/private. The imagined boundary in the imagined nation/State/Community. The Lebanese case. Feminist Review, Number 57, Autumm, 1997. 71-90.

Titmuss, R. M. (1974). What is Social Policy?, in: id., Social Policy. An Introduction, London: Allen and Unwin, 23-32 (ch. 2; the chapter dates from a recurring introductory lecture series at the LSE last held in 1973) [Welfare States, vol. 1: 138-47].

Viswanathan, G. (1995). Beyond orientalism: Syncretism and the politics of knowledge. Stanford Humanities Review, 5, No 1 (1995): $19-34$.

Weber, M. (1991). Economía y sociedad, Buenos Aires. FCE.

Woller, G. M. (1996). Business ethics, society, and Adam Smith: Some observations on the liberal business ethos. The Journal of SocioEconomics Volume 25, Issue 3, 1996, Pages 311-332. 